109

Received: July 8, 2009

Accepted: November 13, 2009
Macedonian Journal of Animal Science, Vol. 2, No. 2, pp. 241-245 (2011)

In print ISSN $1857-6907$

On line ISSN $1857-7709$

UDC: 63 (497.2)

Original scientific paper

\title{
NATURAL HABITATS SITUATION IN INTENSIVE AGRICULTURAL REGIONS IN BULGARIA
}

\author{
Radmil Nikolov \\ University of Economics - Varna, 77 Kniaz Boris I Blvd, Varna, Bulgaria \\ radmil.nikolov@gmail.com
}

\begin{abstract}
In the beginning of the new millennium increasingly topical issue becomes the impact of anthropogenic activities on natural habitats and the creation of semi-naturals as a consequence of the economic activity of society in the context of sustainable development to ensure both stability of agricultural production and storage conditions for the existence of species in ecosystems. Objects of the study are the municipalities of Varna and Dobrich in Northeastern Bulgaria. The aim of this paper is to examine and assess the situation and problems of natural and semi-natural habitats in areas with intensive agriculture and tourism in Northeastern Bulgaria. The following tasks are solved in order to achieve this goal: 1) To analyze the condition of natural and semi-natural habitats. 2) To reveal the problems of natural and semi-natural habitats in areas with intensive agriculture and tourism. 3) To formulate recommendations to improve the state. The methods used for achieving this goal and resolving the tasks are analysis and synthesis, systemic and structural approach, induction and deduction, statistical calculations.
\end{abstract}

Key words: sustainable development; intensive agriculture; habitat conditions

\section{СОСТОЈБА НА ПРИРОДНИТЕ СТАНИШТА ВО РЕГИОНИТЕ СО ИНТЕНЗИВНО ЗЕМЈОДЕЛСКО ПРОИЗВОДСТВО ВО БУГАРИЈА}

Во почетокот на новиот милениум сѐ поактуелно станува прашањето на влијанието на човековата активност врз природните станишта и нивно деградирање како последица на стопанската дејност на општеството. Во контекстот на постојниот развој потребно е да се обезбеди не само стабилност на земјоделското производство, туку и зачувување на условите за постоење на видовите во екосистемот. Предметот на опсервацијата беа општините Варна и Добрич во Бугарија. Целта на научната обработка беше изучување и оцена на состојбата на природните и полуприродните станишта во области со интензивно земјоделско производство и туризам во североисточна Бугарија. За да се постигне целта, неопходно е да се исполни следното: 1) Да се анализира состојбата на природните и полуприродни станишта. 2) Да се откријат проблемите на природните и полприродни станишта во области со интензивно земјоделско производство и туризам. 3) Да се формулираат препораки за подобрување на состојбата на природните стаништата.

Клучни зборови: одржлив развој; интензивно земјоделско производство; состојба на станиште

\section{INTRODUCTION}

The scientific and technical development and the increasing intensity of production lead to constant speed-up of the world concern about the Earth status. The planet's general warming, ozone depletion, unscrupulous clearing of the tropical forests, acid rain increase, uncontrolled population growth, continuous diminishing of millions of hectares fertile land, accompanied by increase of ra- dioactive and other toxic wastes, and strong even dangerous pollution for some regions, awake a reasonable concern for the future of our planet. The mankind faces the ecologic crisis that reveals the most significant problem of the XXI century agenda.

One of Bulgaria's greatest challenges during the economic recession is to provide a balance between the sufficient production of foodstuffs, sustainable rate of employment and preventive envi- 
ronmental protection. Organic farming and other integrated agri-environmental activities are specific practices that directly contribute to the sustainable rural development in Bulgaria and to the development of the country as a whole. They may lead to a stabilization of ecosystems, preservation and restoration of natural resources and at the same time rural development and uncultivated land diminishing.

The aim of this study is to examine and assess the situation and problems of natural and semi-natural habitats in areas with intensive agriculture and tourism in Northeastern Bulgaria.

\section{MATERIAL AND METHODS}

For achieving the aim the following tasks are solved:

$\checkmark$ The condition of natural and semi-natural habitats is analyzed.

$\checkmark$ The problems of natural and semi-natural habitats in areas with intensive agriculture and tourism are solved, and state improved recommendations are formulated based on them.

The used methods are analysis and synthesis, systemic and structural approach, induction and deduction, statistical calculations.

\section{RESULTS AND DISCUSSION}

The terms of habitat or natural habitat, are used within the present paper as synonyms, according to Directive 92/43 EEC for Habitats. They can be defined as follows: terrestrial or aquatic areas distinguished by geographic, a-biotic and biotic features, either entirely or semi-natural. Natural habitat types are threatened with extinction in their natural habitat. They have also a small natural area due to their decrease or their limited area. Essentially they represent one or some of the following five bio-geographical regions such as Alpine, Atlantic, Continental, Moroccan and Mediterranean.

The Bulgarian state establishes and provides functioning of the preserved territories as part of the regional and world network of similar territories in accordance with the international agreements of environmental protection where as the
Republic of Bulgaria is one of the parties. The preserved territories aim to protect the biological variety within the ecosystems and the one of the natural processes as well as the variety of typical or remarkable objects of the inanimate nature and landscapes.

The Protected Areas Act regulates the categories of protected areas, their purpose and protection status and use, as well as disclosure and management. The Act aims at the protection and preservation of protected areas as national and universal treasures as well as a special form of native nature protection, contributing to the development of culture and science, and to the welfare of society. Six main categories of preserved territories have been defined such as reserve, national park, natural landmark, maintained reserve, natural park and protected area.

- Reserves are announced to be samples of natural eco-systems, including the nature and/ or remarkable wild plant and animal species and their habitats.

- National parks are announced to be areas whose boundaries do not fall within settlements and include a great variety of plant and animal species and habitats, with characteristic and remarkable landscapes and objects of inanimate nature.

- Natural landmarks are announced to be remarkable or characteristic objects of inanimate nature, with characteristic and remarkable landscapes and objects of inanimate nature such as rock formations, rock discoveries with scientific value, pyramids, caves, caverns, waterfalls, deposits of fossils and minerals, sand dunes and others that are exceptional value because of their inherent rarity, representativeness, aesthetics and are significant for science and culture.

- Maintained reserves are announced to be ecosystems, including rare or endangered wild animal and plant species and their habitats. In comparison to the category reserve, there is a human intervention applied within the maintained reserves. The main purpose is to preserve and sustain specific conditions that are necessary for providing balance within the ecosystems. Usually the maintained reserves have smaller territory than more reserves and require more active monitoring.

- Natural parks are announced to be areas encompassing diverse eco-systems with variety 
of plant and animal species and their habitats, with characteristic and remarkable landscapes and objects of inanimate nature. Protected areas are announced to be areas with typical or remarkable landscapes, including those resulting from the harmonious coexistence of man and nature or habitats of endangered, rare or vulnerable plant and animal species and communities.

National parks, reserves and maintained reserves are exclusive state ownership. The rest of the categories might be public state, public municipal and/or private ownership. The announcement of a protected area cannot alter the land ownership, forests and water areas within them. Bulgaria is among the richest countries in Europe regarding unique flora and fauna (bio-diversity), variety of habitats, vast forests and other resources with organic importance. Actually the whole range of main European natural habitats could also be found in Bulgaria. Among them are the forests located at high altitude as well as the costal lakes and sand dunes.

The great variety of Bulgarian natural heritage includes forests that represents over one third of its territory, the fisheries in the Black Sea and rivers, fertile agricultural land and wild flora and fauna that is of economic importance such as medicinal plants collected for the local industry and exports. In Bulgaria there are 29.000 animal species including 94 mammals, 405 bird species, 36 reptiles, 16 amphibian, 207 species of sea and freshwater fishes and over 27.000 species of insects and other invertebrates.

These resources are vulnerable by the people's anthropogenic activities. The evidence can be seen from the number of the local species that either disappear in recent decades or change to vulnerable, endangered or critically endangered at this time.

The Bulgarian Red Book includes 750 plant and 150 animal species that are threatened with extinction. The human economic activities cause a number of problems, such as:

- Destruction of habitats and isolation of natural habitats caused by the tourism development, roads, industry;

- Altering species composition caused by the unification of landscapes due to intensive agriculture;
- Destruction of individual species due to overexploitation by hunting, poaching and direct destruction;

- Extinction of many aquatic representatives due to drainage and water pollution or caused by diminishing food stocks.

These economic activities cause anxiety/trouble to the species and disturb the habitats. Each event that leads to a long-term decrease of populations as well as a risk of reducing the area of the habitat and/or decreasing the territory of habitats can be defined as anxiety/trouble to the species that are the protected object within a given area. The disturbance of habitats can be defined as follows: each event leading to diminishing of areas that belong to a given natural habitat as well as any deterioration of factors that are necessary for its long-term maintenance. The balance between the environmental protection and the needs of industries, agriculture and tourism enables the preservation, protection and improvement of these aspects of our natural heritage.

The expected development of agricultural production as a result of the EU-programme and politics application may lead to intensified production and respectively to soil deterioration. The use of the EU-structural funds is a pre-requisite for the development of organic agricultural production and application of practices in accordance with the ecological standards that will enable the protection of soil fertility and creation of ecological agricultural lands. There is recorded evidence that a small proportion of lands in Bulgaria were polluted in the past and during the last $7-8$ years there are no records of any new pollution. More significant is the problem associated with the process of soil erosion that affects nearly three-fourths of the territory of the country.

The current decreasing trends of farming in Bulgaria lead to diminishing significance of grasslands as food resources for farming animals. As a result, much of the grassland territory has been ploughed up and turned into farmland, whereas a significant proportion of the pastures has been abandoned. The pastures and meadows represent around $30 \%$ of the agricultural land in Bulgaria, as per the official statistical data from 2004. Most of the grass eco-systems excluding the alpine pastures and meadows are semi-natural. Within this category some of the abandoned farmland long ago can be included. This portion represents $7.8 \%$ of 
all agricultural lands and features a restoration of natural vegetation. The pastures with low exploitation as well as small areas/ strips of land with grass vegetation in between the farming land could also be included in this category.

As per a research upon grassland ecosystems in Bulgaria, carried out from 2001 until 2004 by the Institute of Botany at the Bulgarian Academy of Sciences (BAS), nearly $40 \%$ of grassland ecosystems have been threatened to be ploughed-up or abandoned. According to the research the main threats for meadows and pastures are the following:

- Overgrowth with trees and shrubs (21\%);

- Plough-up and alteration to farming land $(17 \%)$;

- Overgrazing (6\%);

- Alteration of land usage (5\%);

- Soil erosion $(4 \%)$;

- Construction (4\%).

According to the National Strategy for Biological Diversity Protection (1995) the grassland eco-systems and the wetlands are among the most vulnerable and threatened with distinction habitats in Bulgaria.

The North-eastern Bulgaria is featured by a strong developed agricultural sector as well as a tourism industry due to the favourable combination of natural-climatic factors and the geographical location. The Varna region is knows for its preserved natural potential where as the environmental parameters in almost whole territory are significantly below the European and Bulgarian norms. The only exception is the Varna-Devnya region that is characterized as "hot spot", where main sources of atmospheric pollution and lake pollution have been concentrated (Varna lake and Beloslav lake). The parameters of the Black Sea coast and the resort areas comply with the requirements for tourism and recreation, including the EU-requirements.

The Black Sea zones for using sea water meet the requirements of the EU Regulation 76/160 and national standards in $92 \%$ of the conducted research. Pollution has been registered in lower parts of rivers the Provadjiska - the Devnenska and the Kamchia. There is a wide network of protected territories within the region - natural sights, reserves and maintained reserves, protected areas, mainly related to the biological diversity protection and natural phenomena.
Due to the favourable physical-geographical factors in the Dobrich region - flat relief and a good soil structure, there is a big portion of agricultural territories $-80.5 \%$ whereas the average for the country is about $65 \%$. Of all the area, cultivated land comprised $73 \%$ of the territory which is a high percent in comparison with the average levels in the country - 43.3. The dominant share belongs to the fields in comparison with the perennial crops and pastures in all municipalities.

The forest areas have only a very small share, namely just $12.1 \%$, whereas the average share for the whole country is about $34 \%$. However, that percentage is mainly due to the specially established field protecting forest belts. The share of real forests is very low - they are mostly located along the Danube River and the Suha River as well as the Batova River.

The share of corrupted and unsuitable territories is relatively small $-0.9 \%$ as for $2.6 \%$ average in the country. The main reason for these figures is the small proportion of unsuitable territories in the area. A further reason may be the fact that the heavily polluted and eroded lands have not been included in the recorded balance of the area. The included land types are just the visibly disturbed soils such as stone-pits (quarries), mines, landfills. In some agricultural lands pollution can be observed due to the continued use of fertilizers and pesticides in the recent past.

On the territories of the Varna and the Dobrich regions there are 52 protected areas with total of 6747.51 ha. There are 2 reserves -1555.8 ha, 5 well-kept reserves -417.6 ha, 35 protected biological diversity areas -3270.64 ha, 9 natural landmarks - 182.78 ha and 1 natural park of 1320.7 ha which is extremely rich because the climate, geology, and hydrological condition are of great variety. The major European habitat types can be found here. A significant number of unique and representative communities and ecosystems could be added also as they are extremely valuable in terms of biological diversity. The high level of endemism is of a particular interest - the species that are presented only here and nowhere else in the world, and a number of rare species, many of which are included in the World's list of species threatened from extinction.

Biological diversity has to be preserved in its natural environment, to enable the species to exist and to develop normally. There are activities that have been introduced for habitat protection such as 
limited use of pesticides and fertilizers in agriculture, implementation of programs for organic agriculture and livestock, effective control for reduction of emission pollution regarding air, water and waste management, technological upgrade of production processes.

During the last few years there is a tendency for reducing land and soil degradation. On the territory of the researched regions sour and erosion soils are not reported. Permanent winds with high intensity in Dobrich are pre-requisites for wind erosion. As to fight with the erosion processes anti-wind belts have been planted and high-technological agriculture has been applied. The problem with unused pesticides was completely solved in 2007. There are no cases registered regarding pollution due to expired plant protection chemicals.

The trend is kept as regards the increased number of conducted checks on the protected territories such as 508 in 2003, 513 in 2004, 605 in 2005, 776 in 2006, 891 in 2007. As a result of the undertaken measures conditions for protecting biological diversity and protected areas have been created. Detailed information has been provided in the media regarding the role of wild plants for protecting ecological equilibrium and for damage for wild plants gathering with a commercial effect. The analysis of the carried out check-ups awareness campaigns and media appearances over the previous three years shows that there is a negative trend concerning sales of wild plants flower at the flower market places and in the flower shops. Concerning protection and sustainnable use of medicinal plants, there were 10 books registered for herb-gathering and -preparing points during 2007.

As a result of good persuasion, in order to promote the prohibitive and permissive regime for protected species throughout the country under the Biological Diversity Act, it can be concluded that citizens meet the legal requirements for notification the ecological inspection institution in case of found dead bodies or such in helpless state.

\section{CONCLUSIONS}

It can be summarized that the undertaken measures aiming at proclamation for protecting natural habitats and priority spices which are of the EU interest are a global responsibility of all member-states. The conditions of natural habitats on the European territory of member-states are constantly deteriorating and a great number of wild animals and plant species are in serious danger. Protected habitats and species are part of the natural heritage of the Community. It is imperative that measures are taken on the Community level for their protection. The establishment of the united European ecological network of special protected zones Nature 2000, passing Regulations, statutory and sub delegated legislation for protection and improvement of environment quality helps for the harmonization of the legislation of member-states and establishment of optimal conditions for recreation and sustainable management of biological diversity of the protected areas.

\section{REFERENCES}

[1] DIRECTIVE 92/43/EEC from 21.05.1992.

[2] Protected Areas Act, DV, N 133 from 11.11. 1998, DV, N19 from 13. 03. 2009.

[3] Biological Diversity Act, DV, N 77 from 9. 08. 2002.

[4] Environmental Protection Act, DV, N 91 from 25. 09. 2002, DV, N 19 and N 35/2009.

[5] Research upon grassland ecosystems in Bulgaria, carried out from 2001 until 2004 by the Institute of Botany at the Bulgarian Academy of Sciences (BAS).

[6] National Strategy for Biological Diversity Protection (1995).

[7] National Plan for Biological Diversity Protection 20052010

[8] Petrova N., V. Gaidarjieva (2008): Conditions and perspectives for sustainable land management, Management \& Sustainable Development, University of Forestry, Vol. 21, № 3-4, pp. 134-137.

[9] Baldock, D. (1999): Indicators for High Nature Value Farming Systems in Europe, Chapter 9, pp. 121-135, In: F. Brouwer and B. Crabtree (eds.), Environmental Indicators and Agricultural Policy, CAB International, Wallingford, United Kingdom. 